Akreditasi KEMENRISTEKDIKTI, Nomor: 148/M/KPT/2020
hettp: / /jurnal.stkippersada.ac.id/jurnal/index.php/VOX

\title{
PENGEMBANGAN PERMAINAN KARTU KUARTET MATERI ASAM, BASA DAN GARAM
}

\author{
Siska Putri Damayanti ${ }^{1}$, Eny Enawaty ${ }^{2}$, \& Masriani $^{3}$ \\ ${ }^{1,2,3}$ Fakultas Keguruan dan Ilmu Pendidikan, Universitas Tanjungpura \\ Email:siskaputridam@gmail.com ${ }^{1}$,eny.enawaty@fkip.untan.ac.id ${ }^{2}$, masriani@fkip.untan.ac.id ${ }^{3}$
}

\section{INFO ARTIKEL}

Riwayat Artikel:

Menerima : 14 Juni 2021

Revisi : 08 Agustus 2021

Diterima : 12 Agustus 2021

\section{Kata Kunci:}

Kartu Kuartet, Asam Basa Garam, Kelayakan, Respon

Keywords:

Quartet Card, Acid Base Sald, Feasibility, Response

\section{Korespondensi:}

Siska Putri Damayanti

Fakultas Keguruan dan Ilmu

Pendidikan, Universitas

Tanjungpura

Email:

siskaputridam@gmail.com

\section{ABSTRAK}

Penelitian ini bertujuan untuk menentukan tingkat kelayakan dan respon guru terhadap Permainan Kartu Kuartet pada materi asam basa, dan garam di SMP Negeri 9 Pontianak. Bentuk penelitian dan pengembangan adalah (R\&D) yang mengadopsi model pemngembangan ADDIE. Pengambilan data untuk mengetahui respon guru dengan cara memberikan angket kepada 3 Guru IPA di sekolah yang diteliti. Hasil pengolahan data menunjukkan bahwa Permainan Kartu Kuartet yang dikembangkan layak digunakan dalam pembelajaran ditinjau dari aspek kelayakan Bahasa 100\% (sangat layak), media 100\% (sangat layak) dan materi 91,66\% (sangat layak), dan respon guru sebesar $81,24 \%$ terhadap Permainan Kartu Kuartet. Hal ini menunjukkan di SMP Negeri 9 Pontianak tergolong kategori sangat tinggi. Dengan demikian Permainan Kartu Kuartet dapat digunakan pada pembelajaran materi Asam Basa dan Garam sebagai media pembantu dalam pembelajaran.

\section{ABSTRACT}

This research was conducted to determine the level of feasibility and teacher response to the Quartet Card Game on acid base and salt material Junior High School 9 Pontianak. The form of research and development is $(R \& D)$ which adopts the ADDIE development model. Collecting data to determine the teacher's response by giving a questionnaire to 3 science teachers in the schools studied. The results of data processing show that the developed quartet card game is suitable for use in learning in terms of the percentage of language feasibility of $100 \%$, media is $100 \%$, in the proper category and material is $91,66 \%$, with the very feasible category, and the teacher's response was 81,24\% for the Quartet Card Game. This shows that Junior High School 9 Pontianak is in the very high category. This the Quartet Card Game can be used in leraning of Acid Base and Salt materials as an auxiliary medium in learning.

\section{PENDAHULUAN}

Ilmu pengetahuan alam termasuk dalam mata pelajaran kimia yang bersifat abstrak, materi pelajaran kimia juga banyak menyajikan pengalaman dalam kehidupan sehari-hari peserta didik. Selain itu, beberapa materi sulit diilustrasikan dan sulit diajarkan oleh guru sehingga sulit dipahami peserta didik baik konsep maupun penerapannya (Wati \& Iriani, 2016).
Teknik pembelajaran kimia yang cocok untuk materi yang abstrak adalah dengan cara membayangkan atau menggunakan media gambar yang terkait dengan materi tersebut. Gambar dapat membantu peserta didik mengingat materi kimia yang dibahas. Namun cara-cara tersebut tidak mudah dipahami peserta didik apabila cara penyampaian pebelajaran tidak tepat. Guru dapat memperbanyak ide dan gagasan untuk 
membantu memaksimalkan kemampuan berpikir peserta didik dengan cara menyampaikan materi pelajaran agar dapat diserap dan diingat dengan baik oleh peserta didik, yaitu dengan sumber belajar yang tepat yaitu pemakaian media pembelajaran. Media pembelajaran dapat menarik perhatian peserta didik dan menumbuhkan motivasi belajar sehingga peserta didik bisa lebih aktif berinteraksi langsung dengan lingkungannya, serta peserta didik mampu belajar sendiri sesuai minat dan kemampuannya (Prima, 2015).

Peserta didik masih merasa sulit dalam memahami belajar IPA karena beberapa materinya bersifat abstrak yaitu pada materi asam, basa, dan garam. Selain abstrak, materi ini bersifat kontekstual yang dimana konsep materi dengan kehidupan sehari-hari berkaitan sangat erat. Materi asam, basa, dan garam ditemukan konsep yang penting yaitu pengamatan peserta didik dan diharapkan peserta didik dapat mengamati gejala-gejala, menggolong-golongkan, membuat dugaan, menjelaskan, dan menarik kesimpulan. Selain itu, materi asam, basa dan garam sangat banyak konsep penting yang cenderung bersifat hapalan dan konsep-konsep yang saling berkaitan. Ini membuat kondisi pembelajaran kimia menjadi tidak menarik, tidak disenangi dan demikian peserta didik mendapat hasil belajar yang rendah. Hal ini juga membuat mereka cenderung kurang aktif pada saat proses kegiatan belajar mengajar berlangsung dan kurang mampu membangun konsep tersendiri melalui pembelajaran dikarenakan yang lebih dominan berperan di kelas adalah guru.
Dibuktikan dengan hasil belajar harianpeserta didik kelas VII SMP Negeri 9 Pontianak di beberapa kelas diketahui bahwa sebagian besar peserta didik tidak tuntas pada materi asam, basa dan garam. Ketuntasan paling tinggi diperoleh peserta didik kelas VII D yaitu 97\%, kelas VII B 76\% dan peserta didik kelas VII A memiliki ketuntasan 0\%. Ini menunjukkan tingkat pemahaman peserta didik mengenai pelajaran IPA khususnya asam, basa dan garam di sekolah masih rendah.

Masalah dalam kegiatan belajar mengajar dapat diatasi melalui penggunaan media. Media adalah alat yang berguna untuk membantu guru dalam menjelaskan materi pada kegiatan belajar mengajar serta untuk memudahkan pemahaman peserta didik terhadap materi yang disampaikan (Nunuk, 2018). Dalam pembelajaran di kelas harus menggunakan media yang sesuai dengan karakterisitik materi dan peserta didik. Penggunaan media yang kurang tepat menyebabkan tujuan pembelajaran yang diinginkan tidak akan tercapai. Nunuk (2018) menyatakan, bahwa media adalah penyalur pesan atau informasi dari sumber pesan ke penerima yang dapat merangsang pikian dan membangkitkan semangat peserta didik. Dengan demikian pembelajaran yang tidak menggunakan media dengan maksimal tidak dapat memberikan pengalaman yang menarik dan membuat peserta didik tidak semangat untuk belajar.

Hasil wawancara terhadap peserta didik rendahnya hasil belajar diketahui bahwa salah satu penyebab adalah media yang digunakan saat kegiatan belajar mengajar yang digunakan guru kurang mampu memotivasi peserta didik, 
sehingga peserta didik hanya menghafal saja dan cenderung lupa. Hal ini mengakibatkan peserta didik tidak bisa menjawab soal pada saat evaluasi.

Berdasarkan permasalahan tersebut maka media edukasi berupa permainan kartu kuartet yang diharapkan mampu membuat menyelesaikan permasalahan di sekolah. Dengan media tersebut peserta didik akan merasa nyaman dan tertarik untuk mengikuti pembelajaran di dalam kelas khususnya materi pada asam, basa dan garam. Menurut Suryana (2018) belajar sambil bemain yang disebut dengan permainan edukasi adalah permainan didesain untuk belajar, serta permainan yang berisi gabungan konten edukasi, prinsip pembelajaran, dan memiliki karakteristik interaktif, menarik, dan menyenangkan. Permilihan media kartu kuartet sebagai media untuk meningkatkan minat belajar peserta didik, karena kartu kuartet merupakan suatu bentuk permainan kartu bergambar yang dapat di lihat langsung, sangat informatif,dan dapat dilihat berulang-ulang. Sehingga, peserta didik akan lebih mudah memahami materi yang sering peserta didik lupakan yaitu asam, basa, dan garam. Selain itu, media tersebut dapat meningkatkan minat belajar peserta didik dan dengan media hasil ulangan akan meningkat. Penelitian Inda Setiyorini (2013), menyatakan penggunaan media permainan kartu kuartet dapat meningkatkan efektifitas dalah belajar, sehingga dapat meningkatkan hasil belajar.

Dengan demikian penelitian tentang pengembangan permainan kartu kuartet pada materi asam, basa dan garam untuk peserta didik kelas VII di SMP Negeri 9 Kota
Pontianak sangat penting dilakukan. Penelitian ini diharapkan dapat mengatasi masalah pembelajaran di SMP Negeri 9 Pontianak.

\section{METODE PENELITIAN \\ Bentuk Penelitian}

Bentuk penelitian pengembangan media permainan kartu kuartet pada materi asam, basa dan garam untuk peserta didik kelas VII menggunakan metode Research and Development, model pengembangan ADDIE. Model ini dipilih karena berpijak pada landasan teoritis design pembelajaran dan mudah dikembangkan secara sistematis dan memiliki lima tahapan yang mudah dipahami, sehingga dapat memudahkan untuk mengembangkan sebuah produk bahan ajar dan alat bantu pembelajaran.

Kelebihan dari model ini yaitu menjadi pedoman yang efektif, dinamis dan berurutan sehingga dapat meminimalisir tingkat kesalahan atau kekurangan produk akhir model ini.

Model ini terdiri dari lima tahapan yaitu analisis, perancangan, pengembangan, implementasi, dan evaluasi yang saling berkaitan secara sistematis. Pada penelitian kali ini model ADDIE menjadi ADD yang hanya sampai tahap pengembangan. Karena saat dilakukan nya penelitian ini dalam keadaan pandemic yang tidak memungkinkan untuk dilakukan nya implementasi dan evaluasi di sekolah.

Berikut tabel langkah-langkah model pengembangan dan indikator yang dicapai pada setiap tahapan nya : 
Tabel 1. Langkah-Langkah Model ADD dan Indikator yang Dicapai.

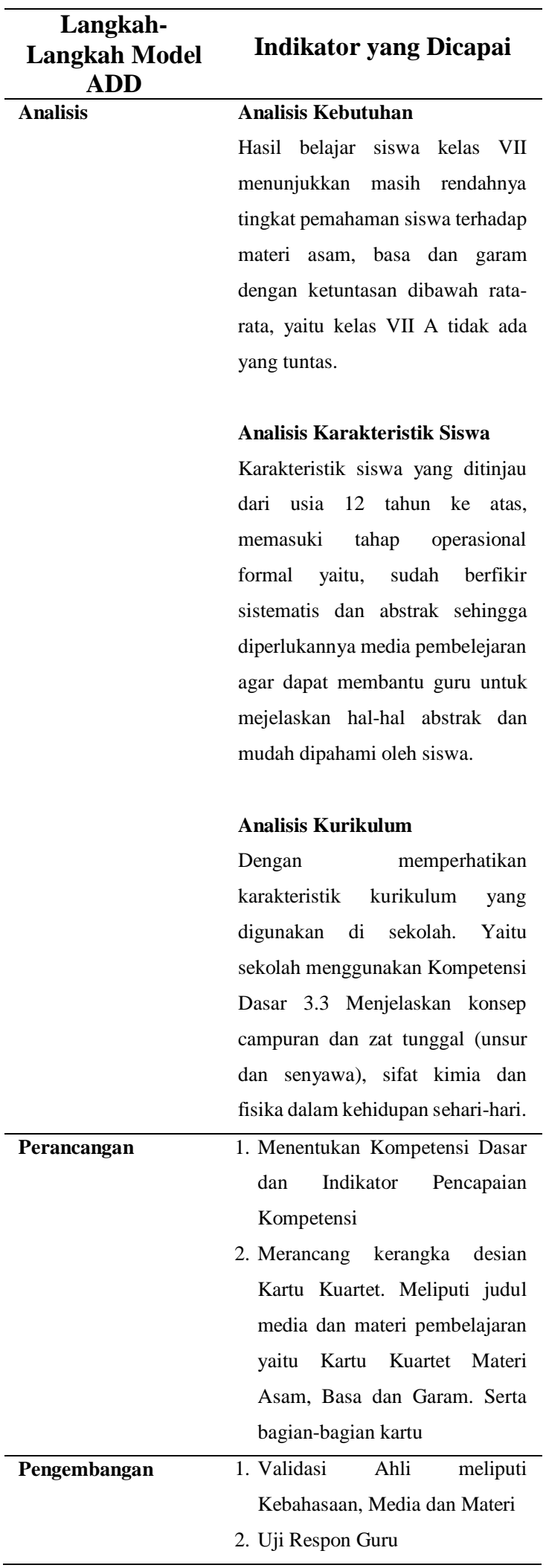

Lokasi dan Subjek Penelitian
Penelitian dilaksanakan di SMP Negeri 9 Pontianak pada tahun 2020. Penelitian ini melibatkan guru kelas VII, VIII dan IX dengan jumlah 3 orang guru IPA yaitu Ely Roheli, S.Pd, Liliyani, S.Pd dan Fitri Fatimah, M.Pd sebagai subjek adalah permainan kartu kuartet.

\section{Pengumpulan dan Analisis Data}

Teknik pengumpulan data menggunakan teknik komunikasi langsung dan teknik pengukuran. Instrumen penelitian menggunakan lembar penilaian kelayakan kebahasaan, media dan materi, serta angket guru terhadap kartu kuartet pada materi asam basa dan garam. Teknik validitas yang digunakan adalah validitas media, bahasa dan materi.

Pengolahan data dilakukan untuk mengetahui kelayakan permainan kartu kuartet pada materi asam, basa dan garam setiap aspek. Menghitung kelayakan permainan kartu kuartet digunakan beberapa perhitungan yaitu dengan 3 ahli sebagai berikut: 1) mengitung skor total tiap-tiap pertanyaan dan 2) menghitung presentase perolehan skor tiap pertanyaan dengan rumus :

$$
\mathrm{P}=\frac{\sum X}{\sum X i} \mathrm{x} 100 \%
$$

Keterangan:

$\mathrm{P}=$ Persentase perolehan skor

$\sum \mathrm{X}=$ jumlah perolehan skor (skor total) tiap pernyataan $\sum \mathrm{Xi}=$ jumlah skor ideal (skor tertinggi)

Sumber : Suharmini Arikunto (2006). Menghitung presentase rata-rata kelayakan kartu kuartet secara keseluruhan dengan rumus:

$$
\mathrm{V}=\frac{\sum P}{n}
$$


Keterangan:

$\mathrm{V}=$ persentase rata-rata kelayakan

$\sum \mathrm{P}=$ jumlah rata-rata persentase skor tiap aspek

$\mathrm{n}=$ jumlah aspek yang dinilai

Sumber : Suharmini Arikunto (2006).

Adapun criteria kelayakan Kartu Kuartet menurut (Ridwan,2008) yaitu:

Tabel 2. Krtiteria Tingkat Kelayakan

Permainan Kartu Kuartet pada Materi Asam

Basa dan Garam.

\begin{tabular}{cc}
\hline Rentang (\%) & Kategori \\
\hline $\mathbf{0 - 4 0}$ & Tidak Layak \\
$\mathbf{4 1 - 6 0}$ & Kurang Layak \\
$\mathbf{6 1 - 8 0}$ & Layak \\
$\mathbf{8 1 - 1 0 0}$ & Sangat Layak \\
\hline
\end{tabular}

Menghitung penilaian kelayakan

permainan kartu kuartet dengan 2 ahli sebagai berikut:

$$
\mathrm{V}=\frac{\mathrm{D}}{\mathrm{A}+\mathrm{B}+\mathrm{C}+\mathrm{D}}
$$

Keterangan:

$\mathrm{V}=$ Koefisien validitas

$\mathrm{A}=$ kedua Ahli tidak setuju

$\mathrm{B}=$ ahli 1 setuju, ahli 2 tidak setuju

$\mathrm{C}=$ ahli 1 tidak setuju, ahli 2 setuju

$\mathrm{D}=$ kedua ahli setuju).

Sumber : Gregory dalam Retnawati, (2016)

Adapun kategori validitas dapat dilihat sebagai berikut:

Tabel 3. Kategori Validitas

\begin{tabular}{cc}
\hline Interval & Kategori \\
\hline$>0,8$ & Tinggi \\
$0.4-0.8$ & Sedang \\
0.4 & Rendah \\
\hline
\end{tabular}

Sumber : Gregory dalam Retnawati, (2016)

Menghitung penilaian kelayakan permainan kartu kuartet dengan menggunakan skala Guttman dengan presentase tiap komponen dihitung menggunakan rumus, sebagai berikut:

$$
\mathrm{P}=\frac{\sum X}{n} \mathrm{x} 100 \%
$$

Keterangan:

$\mathrm{P}=$ Persentase skor ahli $\sum \mathrm{x}=$ Jumlah skor setiap criteria

$\mathrm{n}=$ Jumlah skor ideal

Sumber : Suharmini Arikunto (2006).

Adapun kategori validitas sebagai berikut:

Tabel 4. Kategori Validitas

\begin{tabular}{cc}
\hline Tingkat Pencapaian & Kategori \\
\hline $100 \%$ & Layak \\
$0 \%$ & Tidak Layak \\
\hline & Sumber : Ridwan, (2008).
\end{tabular}

Menghitung penilaian respon guru terhadap permainan kartu kuartet pada materi asam, basa dan garam terhadap tingkat keterbacaan sebagai berikut:

a).mengitung frekuenasi responden

b).menghitung skor total tiap-tiappernyataan sesuai criteria skala Likert sebagai berikut:

Tabel 5. Kriteria Penskoran Skala Likert terhadap Permainan Kartu Kuartet pada Materi Asam, Basa dan Garam.

\begin{tabular}{ccc}
\hline Kategori & $\begin{array}{c}\text { Pernyataan } \\
\text { Positif }\end{array}$ & $\begin{array}{c}\text { Pernyataan } \\
\text { Negatif }\end{array}$ \\
\hline SS & 4 & 1 \\
S & 3 & 2 \\
TS & 2 & 3 \\
STS & 1 & 4 \\
\hline & \multicolumn{2}{c}{ Sumber : Ridwan, (2008) }
\end{tabular}

c). menghitung presentase perolehan skor total tiap pertnyaan dengan rumus:

$$
P=\frac{\Sigma \mathrm{X}}{\Sigma \mathrm{Xi}} \times 100 \%
$$

Keterangan:

$\mathrm{P}=$ persentase perolehan skor

$\sum \mathrm{X}=$ jumlah perolehan skor (skor total) tiap pernyataan

$\sum \mathrm{X}_{\mathrm{i}}=$ jumlah skor ideal (skor tertinggi)

Sumber : Suharmini Arikunto (2006).

d). menghitung presentase total respon dengan rumus:

$$
P_{\text {total }}=\frac{\Sigma \mathrm{P}}{\mathrm{n}}
$$

Keterangan:

$\mathrm{P}_{\text {total }}=$ persentase total respon

$\sum \mathrm{P}=$ jumlah persentase perolehan skor

$\mathrm{n}=$ jumlah pernyataan

Sumber : Suharmini Arikunto (2006). 
e). menentukan criteria respon tiap pernyataan dengan criteria interpretasi (Riduwan, 2008) sebagai berikut:

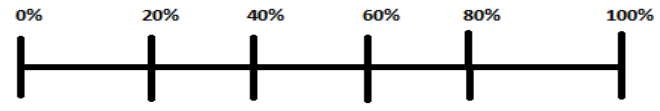

Keterangan:

Angka $0-20 \%=$ Sangat Rendah

Angka 21\% - 40\% = Rendah

Angka $41 \%-60 \%=$ Cukup

Angka $61 \%-80 \%=$ Tinggi

Angka $81 \%-100 \%=$ Sangat Tinggi

Sumber : Ridwan (2008).

Prosedur penelitian dilakukan dengan dua tahap, yaitu tahap persiapan, dan pelaksanaan. Langkah-langkah dalam tahap persiapan adalah: 1). persiapan untuk wawancara ke tempat penelitian.2). menyiapkan kerangka pertanyaan. 3). perijinan dari jurusan PMIPA FKIP UNTAN dan SMP Negeri 9 Pontianak sebagai tempat awal wawancara. Langkahlangkah dalam tahap pelaksanaan adalah a). tahap anlisis 1). anlisis kebutuhan, 2). analisis karkteristik peserta didik, dan 3). analisis kurikulum. b). tahap design 1). menentukan KD dan IPK, 2). merancang kerangka desain, dan 3). membuat strategi pengujian. c). Tahap development 1). validasi desain oleh ahli, 2). revisi desain, 3). uji respon guru, dan 4). penyempurnaan produk akhir.

\section{HASIL DAN PEMBAHASAN}

Penelitian ini menghasilkan Kartu Kuartet materi Asam Basa dan Garam yang dilakukan validasi kelayakan dan respon guru. Pengumpulan data kelayakan dilakukan dengan memberikan lembar penilaian kelayakan pada masing-masing ahli. Ahli kelayakan (validator) dalam penelitian ini yaitu 2 orang ahli bahasa,
2 orang ahli media dan 3 orang ahli kelayakan materi.

Validasi kebahasaan dan revisi kebahasaan dilakukan sebanyak 2 kali. Rekapitulasi hasil validasi para ahli pertama rata-rata bahasa nya sudah tinggi memperoleh skor $60 \%$ dengan saran perbaikan kalimat, penambahan kalimat dan penghilangan kata pada aturan permainan serta terjadi kesalahan pada penulisan pilihan semua nama kartu. Setelah dilakukan perbaikan dilakukan validasi ahli kembali dengan memperoleh skor 100\% dengan kriteria sangat layak. Dengan perbaikan kesalahan pada penulisan pilihan nama kartu (Gambar 1). Berdasarkan saran validator bahasan penulisan pilihan nama kartu bukan kalimat, tetapi nama kartu termasuk frasa maksudnya 2 kata atau lebih yang memiliki makna baru. Jadi awal nama kartu menggunakan huruf kecil. Berikut gambar kartu:

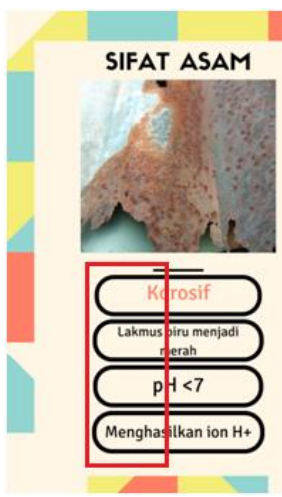

(a)

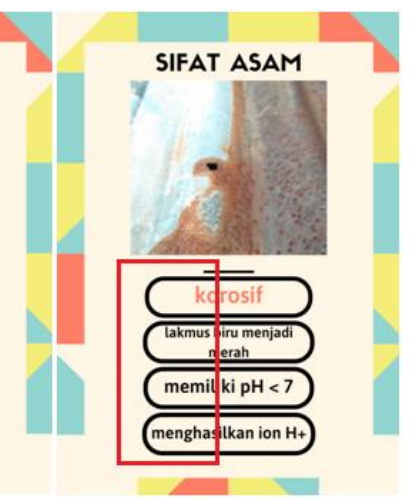

(b)
Gambar 1 Kartu sifat asam, (a) sebelum revisi (b) setelah revisi.

Validasi media dan revisi media, rekapitulasi hasil validasi para ahli menunjukkan secara keseluruhan setiap butir penilaian termasuk dalam penilaian layak dan bisa dilakukan pengujian di tempat yang diteliti 
dengan perbaikan yang diberikan validator. Karena warna gambar masih ada yang belum jelas (Gambar 2), dan warna tulisan dengan background yang kurang jelas (Gambar 3), dan penambahan kata di bagian nama kartu. Berikut gambar hasil validasi media:

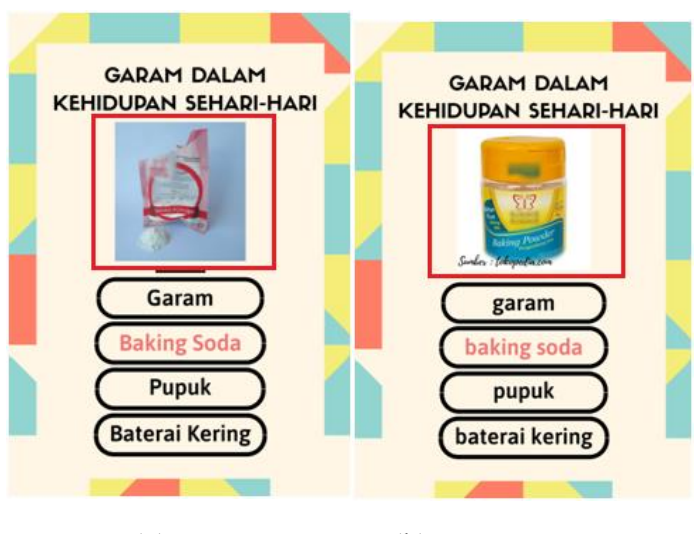

(a)

(b)

Gambar 2. Kartu garam dalam kehidupan sehari-hari, (a) sebelum revisi (b) setelah revisi.

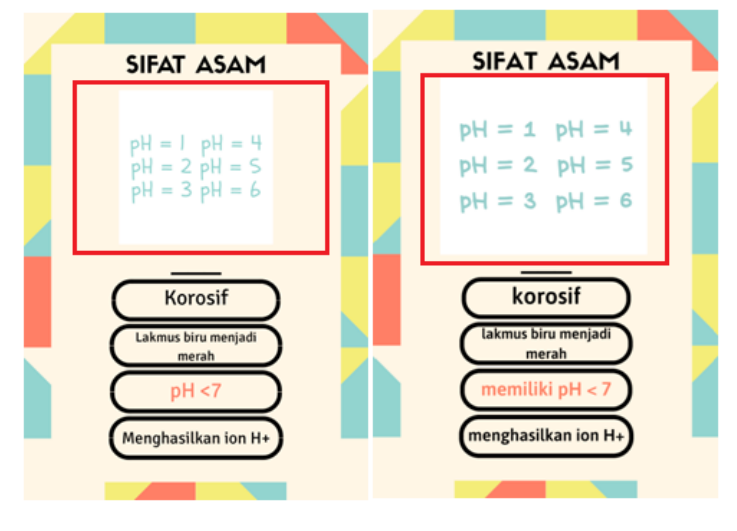

(a)

(b)

Gambar 3 Kartu sifat asam, (a) sebelum revisi (b) setelah revisi.

Validasi materi dan revisi materi dilakukan sebanyak 2 kali. Rekapitulasi hasil validasi para ahli pertama rata-rata materi sebesar $86,10 \%$ dengan saran perbaikan kompetensi dasar (KD) yang disajikan masih mengikuti peraturan menteri Pendidikan dan Kebudayaan nomor 24 tahun 2016 sehingga KD kurang tepat, diganti dengan KD 3.3 pada peraturan menteri pendidikan dan kebudayaan nomor 37 tahun 2018, yaitu menjelaskan konsep campuran dan zat tunggal (unsur dan senyawa), sifat fisika dan kimia, perubahan fisika dan kimia dalam kehidupan sehari-hari.Indikator capaian 3.3.1 dan 3.3.3 terdapat kata "Menjelaskan" tetapi pada media tidak memuat penjelasan sehingga di perbaiki menjadi "Menyebutkan". Pada kelompok kartu sifat garam masih ada gambar yang kurang tepat dari gambar air garam harusnya gambar larutan garam menghantarkan listrik (Gambar 4). Setelah dilakukan perbaikan dilakukan validasi ahli kembali dengan memperoleh skor $91,66 \%$ dengan kriteria sangat layak. Perbaikan materi dapat dilihat secara rinci dengan gambar sebagai berikut:

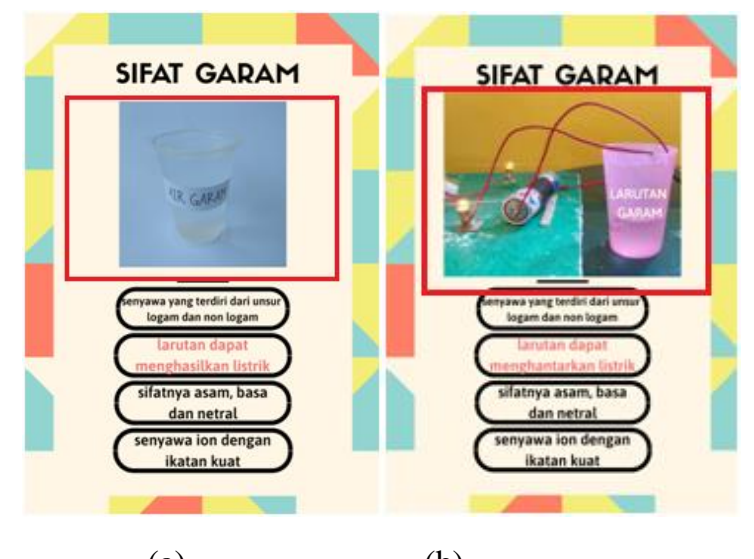

(a)

(b)

Gambar 4 Kartu sifat garam, (a) sebelum revisi (b) setelah revisi.

Uji respon guru dilakukan kepada 3 guru IPA SMP Negeri 9 Pontianak. Hasil analisis angket respon guru terhadap Kartu Kuartet diperoleh persentase aspek Tampilan 83,33\% dan aspek Isi 79,16\%. Jumlah skor dari semua diperoleh uji coba respon guru terhadap Kartu Kuartet pada materi asam, basa dan garam sebesar $81,24 \%$ dengan kriteria sangat tinggi 
dan layak di uji cobakan. Respon guru mendapat skor $81,24 \%$.

Hasil analisis angket respon guru pada pernyataan 1, guru menyatakan tampilan kartu kuartet sangat menarik, warna pada kartu kuartet menarik, dan desain kartu kuartet jelas. Dengan demikian tampilan media dalam kegiatan pembelajaran yang unik membuat peserta didik menjadi tertarik, berpikir kritis, dan mudah merespon pelajaran. Sejalan dengan pendapat Daryanto (2013) desain media yang menimbulkan daya tarik adalah kombinasi antara tampilan warna media, gambar yang ada di dalam media, bentuk media dan ukuran huruf yang sesuai di media serasi. Menurut Desmaria Kristina, dkk (2015) tampilan dalam bahan ajar dibuat menarik dan jelas tata letaknya, sehingga dapat memotivasi peserta didik untuk belajar.

Hasil analisis butir pernyataan 2, guru menyatakan aturan permainan atau petunjuk permainan sudah jelas. Dengan demikian, dapat dikatakan secara keseluruhan petunjuk permainan di dalam Kartu Kuartet sudah jelas untuk guru menjelaskan permainan. Petunjuk permainan dibuat dengan kata-kata yang mudah dengan demikian peserta didik lebih mudah memahami maksud dari arti petunjuk permainan. Sejalan dengan pendapat Arsyad (2010) media pembelajaran yang dibuat menggunakan bahasa yang sesuai dengan KBBI yaitu baik dan benar dapat mempercepat dan mempermudah pemahaman siswa dalam pembelajaran. Menurut Rahmawati, dkk (2016) menggunakan Bahasa yang komunikatif akan membuat peserta didik memahami hal yang dipelajari.
Hasil analisis butir pernyataan 3, guru memberikan skor sangat tinggi pada angket respon yaitu sebesar 83,33\%. Dengan demikian, dapat dikatakan secara keseluruhan tulisan di dalam Kartu Kuartet dapat dibaca dengan jelas. Dibuktikan dengan adanya komentar guru pada angket mengenai media yang dikembangkan menurut guru tulisan di dalam Kartu Kuartet dapat di baca dengan jelas dan desainnya jelas. Artinya tulisan yang ada di dlam Kartu Kuartet tidak buram, tidak pecahpecah dan tidak terlalu kecil. Kejelasan tulisan harus diperhatikan dengan baik karena jika tulisan yang digunakan tidak jelas akan membuat minat guru dan peserta didik kurang dalam membaca tulisan. Pada permainan ini berkaitan erat dengan tulisan jika tulisan yang digunakan tidak jelas maka informasi yang terdapat di media akan kurang dipahami/tersampaikan. Hal ini sejalan dengan pendapat Syahroni (2016) desain media pembelajaran yang menarik untuk pembelajaran adalah tampilan gambar, font, dan kejelasan font yang menonjol. Menurut Asyhari (2016) faktor keindahan dan kejelasan suatu media adalah bentuk tulisan dan gambar estetis, ukuran serasi dan tepat dengan kombinasi warna menarik, sehingga menarik perhatian dan minat peserta didik untuk menggunakannya.

Hasil analisis butir pernyataan 4 pada angket respon guru, guru memberikan skor sangat tinggi pada angket respon yaitu sebesar 83,33\%. Dengan demikian, dapat dikatakan secara keseluruhan Kartu Kuartet dapat membantu guru menjelaskan materi Asam Basa dan Garam. Dibuktikan dengan adanya 
komentar guru pada angket mengenai media yang dikembangkan. Berdasarkan komentar guru pada angket respon kartu kuartet sangat membantu memudahkan penyampaian dan menerapkan materi dengan lengkap serta dapat membangkitkan motivasi peserta didik. Menggunakan media gambar peserta didik lebih tertarik dan lebih paham dalam menangkap informasi saat kegiatan belajar mengajar. Pembelajaran menggunakan media suasananya lebih menyenangkan. Belajar yang menyenangkan dan tidak membuat peserta didik bosan dalam belajar adalah belajar sambil bermain dengan menggunakan media permainan. Adanya media permainan kartu kuartet ini peserta didik akan lebih fokus belajar karna pada kegiatan belajar mengajar tidak hanya mendengarkan dari guru tetapi semua peserta didik berperan dalam pembelajaran. Terdapat interaksi antar peserta didik. Dilihat dari hasil respon guru dapat disimpulkan bahwa Kartu Kuartet dapat membantu guru menjelaskan materi asam basa dan garam. Pembelajaran yang dilakukan dengan cara bermain itu akan membuat peserta didik tidak bosan dalam belajar, karena terjadi interaksi antar peserta didik. Adanya kegiatan pembelajaran yang menyenangkan maka akan mempermudah guru untuk menjelaskan materi karena peserta didik akan lebih semangat, senang dalam belajar, dan tidak mengantuk. Oleh karena itu materi yang akan diterima mudah untuk dipahami. Hal ini sejalan dengan pendapat Sudjana (2009) media adalah alat bantu penyampaian pesan dalam pembelajaran yang digunakan guru dalam proses pembelajaran. Dapat disimpulkan bahwa tanpa adanya dukungan media yang sesuai dalam pembelajaran, kegiatan belajar mengajar yang hanya mengunakan buku pelajaran sebagai satu-satunya sumber belajar, membuat suasana belajar kurang menarik dan membosankan, mengakibatkan peserta didik kurang mengembangkan kemampuan pemahaman dan kreativitas siswa pada materi tersebut. Media permainan kartu kuartet dalam pembelajaran dapat mempermudah guru untuk menjelaskan kepada peserta didik dengan cara belajar sambil bermain suasana di kelas menjadi menyenangkan serta dapat meningkatkan minat belajar siswa sehingga nilai evaluasi yang di dapat peserta didik tinggi. Menurut Asyhari (2016), Menjelaskan materi pembelajaran atau obyek yang abstrak (tidak nyata) menjadi konkret (nyata), seperti menjelaskan materimateri mata pelajaran IPA yang menyajikan gambar-gambar yang abstrak contohnya rangka tubuh manusia. Dengan menggunakan media pembelajaran tulang rangka dan gambar tulang rangka, maka materi pembelajaran yang sebelumnya abstrak atau tidak dapat dilihat langsung menjadi konkret karena dapat dilihat secara jelas dan dapat dirasakan.

Hasil analisis butir pernyataan 5, guru memberikan skor sangat tinggi pada angket respon yaitu sebesar 83,33\%. Dengan demikian, dapat dikatakan secara keseluruhan gambar yang terdapat di Kartu Kuartet membantu guru dalam menjelaskan materi Asam Basa dan Garam. Dengan adanya gambar yang terdapat di kartu kuartet peserta didik dapat mengetahui sifat asam, sifat basa, sifat garam, indicator alami, indicator buatan, serta asam, basa dan garam dalam kehidupan sehari- 
hari. Prastowo (2013) menyatakan untuk menumbuhkan daya tarik dam mengurangi kebosanan bagi pembaca adalah menggunakan gambar-gambar. Menurut Arsyad (2015) media gambar dapat mempercepat pemahaman, memperkuat ingatan dan menumbuhkan minat belajar peserta didik.

\section{SIMPULAN}

Permainan kartu kuartet pada materi asam basa dan garam yang dikembangkan memenuhi kategori sangat layak digunakan sebagai media kegiatan pembelajaran dengan kelayakan bahasa dan media adalah $100 \%$ dan kelayakan materi 91,66\%. Permainan Kartu Kuartet pada Materi Asam Basa dan Garam di SMP Negeri 9 Pontianak memperoleh respon guru sebesar $81,24 \%$ dengan kategori sangat tinggi.

\section{DAFTAR RUJUKAN}

Arsyad, A. 2015. Media Pembelajaran (eighteen ed). Jakarta: PT. Rajawali.

Arsyad, A. 2010. Media Pembelajaran .Jakarta: PT Raja Grafindo Persada.

Asyhari, Ardian. 2016. Pengembangan Media Pembelajaran Berupa Buletin dalam Bentuk Buku Saku untuk Pembelajaran IPA Terpadu. Jurnal Ilmiah Pendidikan Fisika Al-BiRuNi. Vol 05.

Badan Standar Nasional Pendidikan (BSNP). 2006. Instrumen Penilaian Tahap I Buku Teks Pelajaran Pendidikan Dasar dan Menengah. Jakarta: BSNP.

Daryanto. 2013. Media Pembelajaran. Yogyakarta: Gava Media.

Nunuk S,dkk. 2018. Media Pembelajaran Inovatif dan Pengembangannya.Bandung : PT Remaja Rosdakarya.
Prima, N. 2015. Efektivitas Penggunaan Media Pembelajaran Permainan Tradisional Congklak untuk Meningkatkan Kemmapuan Berhitung pada Siswa Sekolah Dasar. Jurnal Ilmiah Psikologi Terapan. Vol 03.

Rahmawati, Ida Sari, dkk. 2016. Pengembangan Media Pembelajaran Menulis Teks Fabel dengan Macromedia Flash Bagi Siswa SMP. Jurnal Pendidikan. Vol 01.

Riduwan. 2008. Pengantar Statistik untuk Penelitian Pendidikan, Sosial, Ekonomi, Komunikasi dan Bisnis. Bandung: Alfabeta.

S. Prihatiningtyas, dkk. 2013. Implementasi Simulasi PhET dan KIT Sederhana Untuk Mengajarkan Keterampilan Psikomotorik Siswa pada Pokok Bahasan Alat Optik. Jurnal Pendidikn IPA Indonesia. Vol 1.

Setiyorini, I. 2013. Penggunaan Media Permainan Kartu Kuartet Pada Mata Pelajaran IPS untuk Peningkatan Hasil Belajar Siswa di Sekolah Dasar. Jpgsd 01(02), 0-216.

Sudjana,N. 2009. Penilaian Hasil Proses Belajar Mengajar.Bandung:PT. Remaja Rosdakarya.

Sugiyono. 2013. Metode Penelitian Pendidikan Pendekatan Kuantitatif, Kualitatif, dan $R \& D$. Bandung: Alpabeta.

Sugiyono. 2015. Metode Penelitian Pendidikan Pendekatan Kuantitatif, Kualitatif, dan $R \& D$.Bandung:Alfabet.

Suharsimi, Arikunto. (2006) Dasar-Dasar Evaluasi Pendidikan. Jakarta:Bumi Aksara.

Suryana, O, A., dkk. 2018. Desain Media Permainan Edukasi Berorientasi Chemo-Edutainment pada Pembelajaran Kimia SMA. Chemistry in Education.

Wati, Nenti Kurnia dan Rilia Iriani. 2016. Pengaruh Model Pembelajaran 
Simayang Tipe II Berbantuan Media Phet Terhadap Hasil Belajar Dan

Kemampuan Representasi Visual

Siswa Pada Materi Larutan Asam

Basa.Jurnal Jurnal Inovasi

Pendidikan Sains, Vol.7. 